\title{
PEMBERDAYAAN PENGRAJIN SONGKET BALI UTARA
}

\begin{abstract}
I Made Pradana Adiputra ${ }^{1}$, Ketut Nala Hari Wardana ${ }^{2}$
\end{abstract}

${ }^{1,2}$ Universitas Pendidikan Ganesha

Artikel

Diterima : 6 Juli 2020

Disetujui : 27 Juli 2020

Email : adiputra@undiksha.ac.id

\begin{abstract}
Abstrak
Desa Jinengdalem merupakan salah satu desa penghasil kerajinan tenun songket utamanya dengan bahan baku benang sutra selain benang emas. Keterbatasan pengrajin dalam melakukan produksi songket dikarenakan dilakukan secara pesanan konsumen, belum terpadunya usaha dalam satu kelompok usaha bersama pengrajin songket. Kegiatan pengabdian pada masyarakat IbM ini juga meningkatkan produksi songket dengan efektivitas penggunaan alat tenun cagcag sebagai alat tradisional yang sampai saat ini belum bisa tergantikan sebagai alat penghasil songket karena pedoman anatomi tubuh pengrajin dalam bekerja dan dapat menghasilkan kain songket dengan kualitas baik. Kegiatan pengabdian yaitu pembentukan KUBE sebagai dasar pembentukan koperasi songket, pengembangan desain motif songket khas Bali Utara, pewarnaan alam dari bahan tumbuh-tumbuhan dari bunga, buah, akar dan kulit tumbuhan dan efektivitas penggunaan alat tradisional cag-cag. Melalui metode sosialisasi, pelatihan dan pendampingan para pengrajin songket Desa Jinengdalem, maka dihasilkan target dan luaran yaitu: pembentukan KUBE, pewarnaan alam benang sutra sebagai bahan dasar songket, produktivitas songket dengan alat tenun cag-cag dan desain motif yang lebih terdiversifikasi sesuai khas Bali Utara (Buleleng).
\end{abstract}

Kata Kunci: Songket, Jinengdalem, Motif Songket, Pewarnaan Alam

\begin{abstract}
Jinengdalem Village is one of the villages producing songket weaving crafts mainly with raw materials of silk thread besides gold thread. The limitation of the craftsmen in producing songket is because it is done by consumer orders, and there is no unified business in a joint business group of songket artisans. The community service activities of the IbM also increase songket production with the effective use of cag-cag looms as traditional tools which until now have not been able to be replaced as songket producers because of the anatomical guidelines of the craftsman's body at work and can produce songket cloth with good quality. Community service activities include the establishment of KUBE as the basis for the formation of songket cooperatives, the development of North Bali typical songket designs, the natural coloring of plant material from flowers, fruit, roots and plant skins and the effective use of traditional cag-cag tools. Through the method of socialization, training and mentoring of the Jinketdalem village songket craftsmen, targets and outcomes were produced: the formation of KUBE, natural dyeing silk threads as the base material of songket, songket productivity with cag-cag looms and more diversified motif designs in accordance with North Bali (Buleleng).
\end{abstract}

Keywords: Songket, Jinengdalem, Songket Motif, Natural Coloration 


\section{PENDAHULUAN}

Tenun Bali merupakan kekayaan tenun nusantara yang identik menggunakan media alat tradisional. Harga produksi yang cukup tinggi dikarenakan proses pembuatannya membutuhkan waktu yang lama. Tingginya harga jual kain tenun ini membuat munculnya kain tenun tiruan yang dijual dengan harga yang murah. Hal ini menyebabkan menurunnya jumlah pengrajin tenun Bali yang berdampak pada hilangnya identitas Bali sebagai pemilik tenun yang asli (Mujaddidah dan Wahyurini (2016). Tenun songket adalah produk kerajinan atau kriya sebagai kekayaan budaya yang berkembang di masyarakat. Ciri khas yang paling menonjol pada tenun songket adalah bentuk ragam hiasnya. Ragam hias tenun songket dibuat dengan teknik pakan tambahan (suplementary weft), dengan cara menambahkan benang pakan pada posisi horisontal kedalam benang lungsi (posisi vertikal) saat proses menenun (Sila dan Budhyani, 2017). Keragaman budaya Indonesia tercermin dari penggunaan desain pakan tambahan yang membuat terciptanya tenunan yang berbedabeda dalam bentuk motif, sehingga memunculkan identitas kelokalan daerah pembuatnya (Purwanti dan Siregar, 2016)

Salah satu hasil tenun songket yang diproduksi di Bali adalah yang dihasilkan pengrajin di Desa Jinangdalem tetap eksis dan mampu bersaing di pasaran. Meski persaingan makin ketat, kain songket yang diproduksi di daerah tersebut, tetap dicari konsumen. Kondisi ini tentu saja menyebabkan kualitas kain songket menjadi hal yang amat penting. Untuk itu, pengrajin songket di Desa Jinengdalem tetap mengutamakan kualitas produk yang akan dijual. Para pengrajin di Desa Jinengdalem mengakui bahwa mereka merasa tidak akan kalah bersaing dengan pengrajin dari kabupten lainnya karena produksi tenun songket khas Desa Jinengdalem memiliki motifnya sendiri (khas Buleleng) dan tidak mungkin akan disamakan dengan motif di luar Kabupaten Buleleng. Pengrajin menyatakan tidak takut akan pengakuan desain motif karena mereka yakin bahwa hanya mereka yang bisa membuat desain motif khas Bali Utara. Pilihan produk ada pada konsumsen yang menjadi pilihan atau seleranya.

Realita di lapangan menunjukkan bahwa (1) Pengrajin melakukan usahanya secara sendiri-sendiri dengan berkelompok dengan ibu-ibu rumah tangga lainnya sebagai pekerjaan sampingan untuk membantu menambah pendapatan keluarga. (2). Manajemen usaha yang dilakukan para pengrajin adalah manajemen usaha rumah tangga secara sederhana dengan satu orang sebagai koordinator atau pengepul. Setiap pengrajin yang dalam hal ini adalah para ibu rumah tangga bekerja dengan alat tenun yang disebut "cag-cag", bekerja sesuai pesanan maupun produksi massa/terus-menerus. (3) Aspek desain motif songket cenderung mengikuti keinginan konsumen meskipun telah ada motif songket khas Buleleng (Bali Utara) telah dimiliki seperti: Cakra Kurung, Semangi Gunung, Tirta Nadi, PotPotan dan Cakar Ayam. Hal ini tentu saja akan menghilangkan motif-motif tersebut dengan motif pesanan secara perlahan-lahan. (4) Proses produksi songket khususnya yang dihasilkan dari alat tenun cag-cag yang dimiliki pengrajin (rata-rata hanya 2-4 alat) tentu saja menghambat produktivitas tenun songket. Menurut ibu Suami, alat tenun cag-cag memang merupakan satu-satunya alat yang digunakan oleh pengrajin, karena kekhususan alat yang disesuaikan dengan semangat pengrajin dalam proses 
tenun berdasarkan anatomi tubuh pengrajin dan dentingan alat cag-cag. Tidak bisa diciptakan alat cagcag baru karena seperangkat alat tenun harus dibuat dari bahan baku kayu dan bambu yang khusus seperti alat prorogan dari bambu berfungsi untuk tempat meletakkan belide dan pebungbungan selama proses penenunan berlangsung. (5). Salah satu kualitas songket adalah terletak pada proses pewarnaan. Selama ini proses pewarnaan songket yang dilakukan pengrajin di Desa Jinengdalem adalah melalui pewarnaan kimia, sementara minat konsumen songket cenderung lebih suka dengan warna-warna alam yang menimbulkan kesan eksklusif dan klasik. Sedangkan proses pewarnaan bahan baku songket berupa benang, tidak dilakukan sendiri oleh pengrajin sehingga lebih menambah biaya produksi songket dan berdampak terhadap harga jual songket.

Oleh karena itu diperlukan pemberdayaan pengrajin kain songket di Desa Jinengdalem tersebut dengan menguatkan permodalan, produksi, pemasaran/promosi melalui penguatan kelompok pengrajin dengan pembentukan kelompok usaha bersama (KUBE). KUBE merupakan kelompok usaha bersama dengan tujuan untuk memberdayakan masyarakat dengan membentuk kelompok-kelompok usaha seeprti koperasi dan sejenisnya (Mardikanto, 2010). KUBE dilakukan melalui pembentukan Koperasi Perempuan Pengrajin Songket. Dengan KUBE melalui koperasi songket maka akses permodalan, produksi dan pemasaran hasil produksi dapat teratasi. Hal lain yang dapat dilakukan adalah penguatan desain motif songket khas Bali Utara (Buleleng) melalui cara penciptaan motif-motif baru dengan mempertahankan motif khas Buleleng yang dimodifikasi motif kekinian mengikuti minat konsumen. Selanjutnya adalah peningkatan produktivitas hasil tenun melalui pengenalan Alat Tenun Bukan Mesin (ATBM) dan pelatihan pewarnaan alam pada benang sebagai bahan baku songket sebagai alternatif penggunaan pewarna kimia yang belum dikuasai oleh pengrajin songket, terlebih penggunaan bahan kimia harus hati-hati dalam proses pewarnaan terhadap bahan baku benang songket.

\section{METODE}

Metode pelaksanaan kegiatan meliputi tahap sosialisasi, diseminasi, tahap penyuluhan dan tahap pendampingan usaha mitra. Langkah-langkah yang dilakukan untuk mengatasi persoalan mitra yaitu:

1. Pembentukan Kelompok Usaha Bersama (KUBE) sebagai dasar pendirian koperasi pengrajin songket, Desain motif songket khas Bali Utara (Buleleng).

2. Motif khas Buleleng dan modifikasi motif kekinian melalui metode pelatihan dan pendampingan kelompok pengrajin.

3. Alat Tenun Bukan Mesin (ATBM)/cag-cag: desain alat tenun cag-cag disesuaikan dengan kondisi/postur pengrajin melalui metode pelatihan dan pendampingan kelompok pengrajin.

Produksi songket dengan proses pewarnaan alam pada benang sebagai bahan baku songket melalui metode pelatihan dan pendampingan kelompok pengrajin. 


\section{HASIL \& PEMBAHASAN}

Berdasarkan permasalahan mitra, target luaran dan metode pelaksaaan pengabdian masyarakat, maka hasil kegiatan diraikan berikut ini.

\section{Pembentukan KUBE}

a. Pada kegiatan ini dilakukan koordinasi dengan pihak Dinas Koperasi dan UKM Kabupaten Buleleng, Dewan Koperasi Indonesia (Dekopin) Buleleng dan Dewan Kerajinan Nasional Daerah Kabupaten/Propinsi Bali. Pembentukan KUBE dalam rangka pembentukan koperasi pengrajin songket ini dilakukan dengan metode sosialisasi dan penyuluhan kepada kelompok pengrajin songket.

b. Pembentukan pengurus (struktur organisasi) koperasi songket sekaligus pendampingan dan penyuluhan manajemen organisasi koperasi.

c. Pengurusan badan hukum koperasi pengrajin songket, melalui pengurusan badan hukum pendirian koperasi pengrajin kepada pejabat yang berwenang yaitu notaris dengan metode pendampingan kelompok pengrajin songket melalui koordinasi dengan Dinas Koperasi dan UKM Kabupaten Buleleng dan Dekopinda Buleleng.

Pada kegiatan pembentukan KUBE ini, pelaksana kegiatan IbM memberikan sosialisasi tentang arti penting KUBE, diantaranya: peningkatan kemampuan berusaha para pengrajin secara bersama dalam kelompok, peningkatan pendapatan, pengembangan usaha dan peningkatan kepedulian dan kesetiakawanan sosial diantara para pengrajin dengan masyarakat sekitarnya.

\section{Motif Songket}

Jenis-jenis kerajinan tenun songket yang dihasilkan oleh perajin Desa Jinengdalem adalah: kain/kemben, saput/kampuh, ada juga beberapa jenis yang lainnya seperti selendang, dan taplak meja. Semua jenis produk ini sebagai ciri produksi perajin Jinengdalem. Sebagai karya seni kerajinan yang tradisional alat-alat yang digunakan untuk memroduksi masih bersifat tradisional, atau disebut juga alat tenun cagcag. Ketekunan dan keuletan para perajin wanita dalam berkarya/menenun menjadi modal dasar sehingga kualitas barang yang dihasilkan menjadi lebih baik.

Bebebarapa motif yang dihasilkan sebagai berikut:

a. Bade atau juga disebut wadah adalah sarana religius dalam upacara ngaben yang digunakan untuk membawa sawa atau jenasah ke setra. Bentuk bangunan wadah/bade ini di hiasi oleh beragam ornamen Bali yang dalam dominasi ornamen patra punggel pada bangunan wadah/bade disebutkan dibagi menjadi tiga bagian yaitu: Bagian kepala, Bagian badan, dan Bagian kaki. 


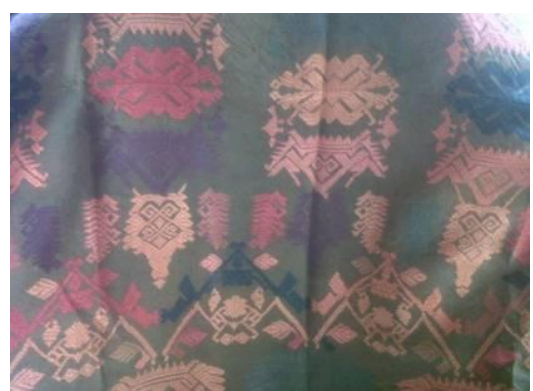

Gambar 1. Songket Motif Bade

b. Motif flora atau patra adalah motif yang paling banyak digunakan dalam kain songket termasuk songket Bali. Motif flora mencakup motif pohon, sulur- suluran, daun, bunga, biji-bijian dan tunas tumbuhan. Bunga secara umum bagi umat Hindu menggambarkan kesucian hati karena itu dipakai untuk memuja Sang Hyang Widhi dan para leluhur. Patra adalah tumbuhan yang merambat dan menjalar sebagai bagian jejepan dari rumus perhitungan wariga dan dewasa ayu dalam kalender bali yang digunakan untuk menentukan hari baik berdasarkan wariga dan dewasa ayu. Contoh motif patra punggel (kiri) dan patra sari (kanan).
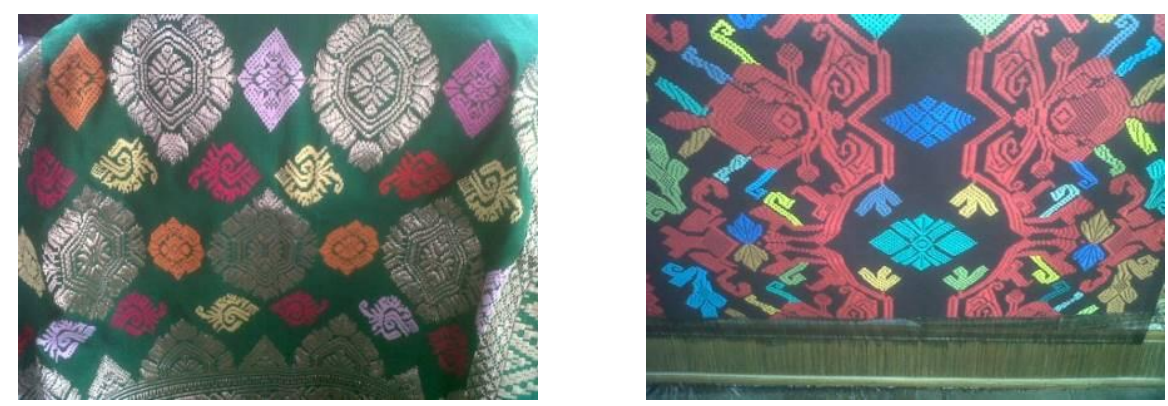

Gambar 2. Songket Motif Flora atau Patra

c. Motif wayang adalah motif yang menggunakan gambar-gambar manusia. Tokoh-tokoh yang digambarkan dalam motif songket Bali ini adalah karakter yang berasal dari epos Mahabarata dan Ramayana. Motif motif seperti cili, wayang dan topeng merupakan simbol penghormatan kepada roh leluhur.

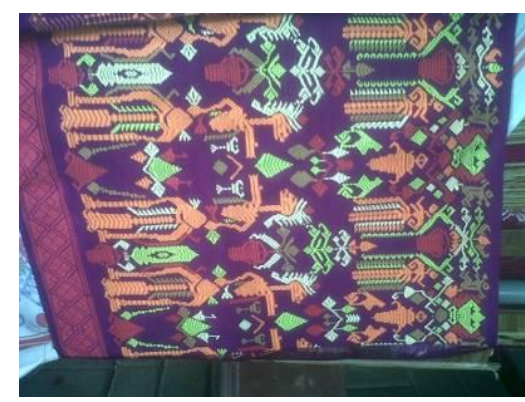

Gambar 3. Songket Motif Wayang

d. Songket bermotif fauna atau karang menampilkan gambar-gambar berbagi jenis hewan. Hewanhewan ini melambangkan sifat-sifat sakral dari dewa-dewa dalam agama Hindu atau juga merupakan sahabat atau tunggangan para dewa. Simbol-simbol hewan yang dianggap sakral antara lain: singa, naga, sapi, angsa, buruk merak, manuk dewata, kupu-kupu dan sebagainya. 
Motif burung merak juga disakralkan karena merak adalah kendaraan dewa Kumara atau Subramanyam.

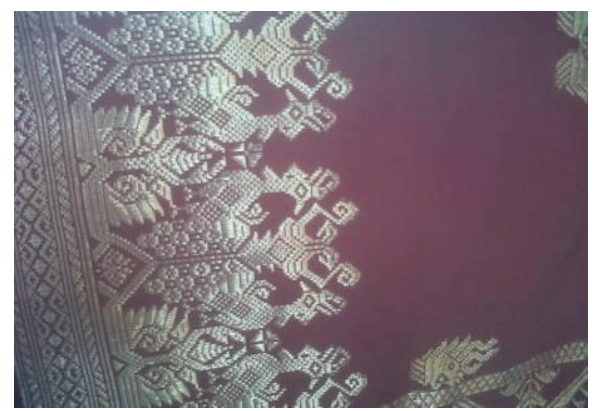

Gambar 4. Songket Motif Fauna atau karang

\section{Proses Pewarnaan Alam}

Proses pewarnaan alam yang dilakukan oleh kelompok pengrajin songket melalui beberapa tahapan dalam melakukan proses ekstraksi/pembuatan larutan zat warna alam yang perlu disesuaikan dengan berat bahan yang hendak diproses sehingga jumlah larutan zat warna alam yang dihasilkan dapat mencukupi untuk mencelup bahan tekstil. Banyaknya larutan zat warna alam yang diperlukan tergantung pada jumlah bahan tekstil yang akan diproses. Perbandingan larutan zat warna dengan bahan tekstil yang biasa digunakan adalah 1:30. Misalnya berat bahan tekstil yang diproses 100 gram maka kebutuhan larutan zat warna alam adalah 3 liter. Sebelum dilakukan pencelupan dengan larutan zat warna alam pada kain katun dan sutera perlu dilakukan beberapa proses persiapan yaitu: proses mordanting melalui perebusan bahan-bahan alam, pembuatan larutan fixer (pengunci warna) dan proses pencelupan dengan zat warna alam setelah bahan di-mordanting dan larutan fixer siap maka proses pencelupan bahan tekstil dapat segera dilakukan melalui proses pencelupan bahan benang sutra ke dalam rebusan selama kurang lebih 30 menit sampai dengan 1 jam.

\section{Alat Tenun Bukan Mesin (alat tenun cag-cag)}

Proses tenun songket oleh kelompok pengrajin songket dilakukan melalui alat tenun cag-cag. Kelompok pengrajin songket di Desa Jinengdalem selama ini masih minim dalam produksi kain tenun songket karena minimnya alat tenun cag-cag yang selama ini dipandang sebagai alat yang masih memberikan kualitas proses penenunan dibandingkan alat tenun bukan mesin. Selain pertimbangan hasil penenunan, dikarenakan karena mahalnya alat ATBM dan kemampuan keahlian pengrajin dalam melakukan proses penenunan songket mengakibatkan para pengrajin masih mempertahankan alat tenun cag-cag. 


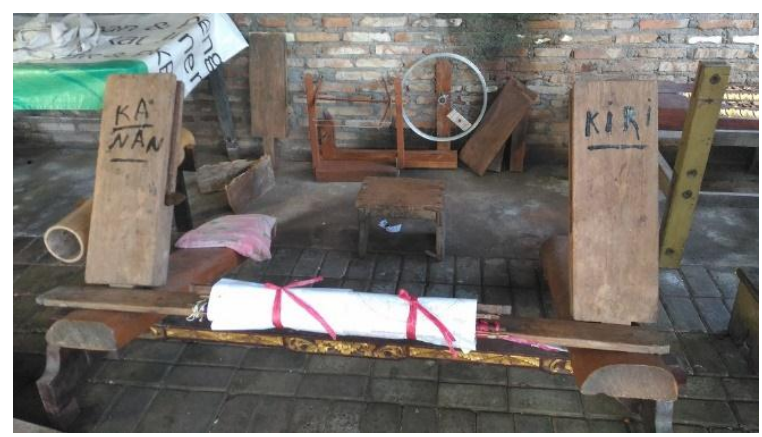

Gambar 5. Alat Tenun Cag-cag

Berbagai jenis songket khas Jinengdalem telah dihasilkan melalui proses penenunan yang secara singkat dapat dijelaskan sebagai berikut:

a. Benang sebagai bahan dasar songket dicuci dengan air kanji kemudian dijemur sampai kering.

b. Setelah kering lalu digulung dengan menggunakan "degkrek" dan "undar".

c. Kemudian dilanjutkan dengan proses "anyinin" dengan alat "panyinan"

d. Selanjutnya proses suntik untuk dimasukkan ke sisir/serat

e. Setelah itu proses disasah/dipanjangkan yang kemudian digulung dengan menggunakan pandalan.

f. Tahap berikutnya adalah membuat motif dengan "guwon"

g. Usai motif dibuat maka diteruskan dengan proses penenunan melalui ruas-ruas bambu di sepanjang bahan dasar benang

Ketahanan pengrajin selama proses penenunan songket didukung oleh beberapa alat yang mendukung alat tenun cag-cag sekaligus sebagai semangat bagi para pengrajin untuk menghasilkan songket yang indah dan berkualitas baik, yaitu: prorogan dan balide. Prorogan dari bambu berfungsi untuk tempat meletakkan belide dan pebungbungan selama proses penenunan berlangsung. Belide yang mengeluarkan lengkingan yang keras dan pebungbungan untuk menambah energi pengrajin dalam menenun.

\section{SIMPULAN}

\section{Kesimpulan}

Kesimpulan yang dapat diperoleh dari pelaksanaan kegiatan pengabdian pada masyarakat yaitu pengrajin songket di Desa Jinengdalem adalah:

a. Tingkat partisipasi yang tinggi dari mitra program pengabdian pada masyarakat memberikan dampak positif bagi pelaksanaan program. Hal ini terlihat dari antusiasme pengrajin songket dalam mengikuti pelaksanaan kegiatan pengabdian, efektivitas komunikasi dan kerjasama antara pengrajin dengan tim pelaksana, sehingga dapat berjalan dengan lancar.

b. Pelaksanaan kegiatan pengabdian pada masyarakat mampu menghasilkan luaran-luaran yang diharapkan oleh tim pelaksana sesuai dengan waktu, target dan luaran yang dicapai dalam kegiatan pengabdian masyarakat ini, yaitu: pembentukan KUBE, motif songket, pewarnaan alam dan produktivitas melalui ATBM (cag-cag). 


\section{Saran}

Songket Jinengdalem yang selama ini lebih banyak dihasilkan dari proses pewarnaan kimia diharapkan akan lebih banyak mendapatkan pemahaman bagi para pengrajin songket untuk menggunakan pewarnaan alam untuk mengurangi dampak buruk lingkungan akibat bahan-bahan kimia. Pengelolaan kelompok pengrajin akan diharapkan akan lebih meningkatkan produktivitas dan keuntungan bagi para pengrajin melalui kelompok usaha bersama pengrajin songket. Bagi pemerintah desa Jinengdalem dan pemerintah kabupaten di Buleleng, untuk memberikan perhatian terhadap perkembangan dan kemajuan songket Desa Jinengdalem sehingga lebih memperkaya motif songket sehingga dapat menjadi sentra industri songket yang dikenal oleh masyarakat baik dalam dan luar negeri.

\section{DAFTAR PUSTAKA}

Mujaddidah, V.V. dan Wahyurini, O.D, 2016, Perancangan Buku Visual Tenun Bali Sebagai Upaya Pelestarian Tenun, Jurnal Sains dan Seni ITS, Vol. 5, No. 2, 411-416.

Mardikanto, T, 2010, Model-Model Pemberdayaan Masyarakat Acuan Bagi Akademisi dan Praktisi Pemberdayaan Masyarakat. Surakarta: Sebelas Maret University Press.

Purwanti, R. dan Siregar, S.M, 2016, SEjarang Songket Berdasarkan Data Arkeologi, Siddhayatra, Vol. 21 (2), 97-106.

Sila, I.N. dan Budhyani, I.D.A.M, 2017, Tenun Songket Buleleng Pada Era Globalisasi, Seminar Nasional Riset Inovatif, Universitas Pendidikan Ganesha. 